\title{
PENGHILANGAN POLUTAN ORGANIK DAN PADATAN TERRSUSPENSI DI DALAM AIR LIMBAH DOMESTIK DENGAN PROSES MOVING BED BIOFILM REACTOR (MBBR)
}

\author{
Removal Of Organic Pollutants And Suspended Solids In Domestic Waste Wate Using \\ Moving Bed Biofilm Reactor (MBBR) Process \\ Oleh : \\ Nusa Idaman Said ${ }^{*}$ dan Teguh Iman Santoso ${ }^{* *}$ \\ ${ }^{*}$ Pusat Teknologi Lingkungan-BPPT, ${ }^{* *}$ Universitas Mulawarman
}

\begin{abstract}
Abstrak
Salah satu alternati teknologi yang dapat digunakan untuk pengolahan air limbah domes adalah Moving Bed Biofilm Reactor (MBBR). MBBR pada prinsipnya merupakan lumpur aktif yan ditingkatkan dengan menambahkan media di dalam reaktor, sehingga terjadi di pengolahan di dalamnya, yakni suspended growth dan attached grou Pada penelitian media yang digunakan adalah bioball yang memiliki luas permukaan $\pm 210 \mathrm{~m}^{2} / \mathrm{m}^{3}$ dengan volume $20 \%$ volume reaktor. Pengolahan dengan MBBR menggunakan variasi waktu tinggal hidrolik (WTH) 12, 8, 6 dan 4 jam, kemudian untuk parameter yang diamati adalah BOD, COD, TSS, suhu dan $\mathrm{pH}$. Hasil penelitian menunjukkan bahwa dengan waktu tinggal hidro WTH) dalam tangki aerasi 12 jam efisiensi penyisihan COD sebesar 81,37\%, BOD sebesar 82,4\%, TSS sebesar 90,05\%. Pada WTH 8 jam efisiensi penyisihan COD sebesar 88,72\%, BOD sebesar 89,7\%, TSS sebesar 92,06\%. Pada WTH 6 jam efisiensi penyisihan COD sebesar 85,48\%, BOD sebesar 80,15\%, TSS sebesar 94,85\%. Pada WTH 4 jam efisiensi penyisihan COD sebesar $81,07 \%$, BOD sebesar 87,88\%, TSS sebesar 94,86\%. Dengan waktu tinggal 4 jam, efluen hasil pengolahan air limbah domestik dengan MBBR sudah memenuhi baku mutu sesuai dengan KEPMEN LH no. 112 tahun 2003 tentang Baku Mutu Air Limbah Domestik dan PERGUB DKI Jakarta no. 122 tahun 2005 tentang Pengelolaan Air Limbah Domestik Di Provinsi Daerah Khusus Ibukota Jakarta.
\end{abstract}

Kata Kunci : Air limbah domestik, MBBR, bioball.

\begin{abstract}
One of the alternati technologies that could be used for domestic wasi water treatment is the Moving Bed Biofilm Reactor (MBBR). MBBR in principle is activated sludge that is increased by adding media in to the reactor, so there are two treatments process happened inside, suspended growth and attached growth. This research is using bioball as a media which has surface area of $\pm 210 \mathrm{~m}^{2} / \mathrm{m}^{3}$ by $20 \%$ volume of reactor volume. Wastewater treatment by MBBR uses variations of Hydraulic Retention time (HRT) 12, 8, 6, and 4 hours, then the parameters measured were BOD, COD, TSS, temperature, and $\mathrm{pH}$. Result of the study shows that within HRT for 12 hours in aeration tank, removal efficiency of COD is $81,37 \%, B O D$ is $82,4 \%$, and TSS is $90,05 \%$. HRT for 8 hours, COD removal efficiency is $88,72 \%, B O D$ is $89,7 \%$, and TSS is $92,06 \%$. HRT for 6 hours, COD removal efficiency is $85,48 \%, B O D$ is $80,15 \%$, and TSS is $94,85 \%$. HRT for 4 hours, COD removal efficiency is $81,07 \%, B O D$ is $87,88 \%$, and TSS is $94,86 \%$. With a retentio time, 4 hours, the effluent results domestic wastewat treatment using MBBR has met quality standards in accordance with KEPMEN LH no. 112 of 2003 on Domest Wastewater Quality Standard and Jakarta Governor Regulatio no. 122 of 2005 on Domest Wastewater Management in Special Province of Jakarta.
\end{abstract}

Keywords: Domestic wastewater, MBBR, bioball.

\section{PENDAHULUAN}

\subsection{Latar Belakang}

Limbah adalah air buangan yang dihasilkan dari suatu proses produksi baik dari kegiatan industri maupun kegiatan rumah tangga. Menurut PP nomor
82 tahun 2001, air limbah adalah sisa dari suatu usaha dan atau kegiatan yang berwujud cair. Sedangkan, menurut Kepmen LH nomor 112 tahun 2003, air limbah domestik adalah air limbah yang berasal dari usaha dan atau kegiatan permukiman (real estate), rumah makan (restaurant), perkantoran, perniagaan, apartemen dan asrama. 
Air limbah kota-kota besar di Indonesia khususnya Jakarta secara garis besar dapat dibagi menjadi tiga yaitu pertama adalah air limbah industri, kedua adalah air limbah domestik yakni yang berasal dari buangan rumah tangga, dan yang ke tiga yakni air limbah dari perkantoran dan pertokoan (daerah komersial). Saat ini selain pencemaran akibat limbah industri, pencemaran akibat limbah domestik pun telah menunjukkan tingkat yang cukup serius. Di Jakarta misalnya, sebagai akibat masih minimnya fasilitas pengolahan air buangan kota mengakibatkan tercemarnya badan-badan sungai oleh air limbah domistik, bahkan badan sungai yang diperuntukkan sebagai bahan baku air minumpun telah tercemar (Said, 2005, 2008).

Untuk mengatasi masalah pencemaran air di wilayah DKI Jakarta sudah sangat perlu untuk membangun fasilitas pengolahan air limbah perkotaan yang memadai. Saat ini yang sering dituding sebagai biang pencemaran lingkungan adalah pihak industri baik industri besar, menengah maupun kecil. Dan untuk industri telah diwajibkan untuk mengolah air limbahnya sebelum dibuang ke perairan umum sampai standar kualitas yang disyaratkan. Sedangkan untuk air limbah domestik, perkantoran dan daerah komersial yang kontribusi pencemarannya mencapai sekitar $80 \%$ dari total pencemaran air di DKI Jakarta, hanya sekitar $3 \%$ yang telah diolah (PD PAL Jaya, 1996).

Dalam proses pengolahan air limbah khususnya yang mengandung polutan senyawa organik, teknologi yang digunakan sebagaian besar menggunakan aktiftas mikroorganisme untuk menguraikan senyawa polutan organik tersebut. Proses pengolahan air limbah dengan aktifitas mikroorganisme biasa disebut dengan Proses Biologis.

Proses pengolahan air limbah secara biologis tersebut dapat dilakukan pada kondisi aerobik (dengan udara). Kondisi anaerobik (tanpa udara) atau kombinasi anaerobik dan aerobik. Proses biologi aerobik biasanya digunakan untuk mpengolahan air limbah dengan beban BOD yang tidak terlalu besar, sedangkan proses biologis anaerobik digunakan untuk pengolahan air limbah dengan beban BOD yang sangat tinggi.

Tetapi ada beberapa kelemahan dalam menggunakan proses pengolahan limbah secara biologis yakni antara lain membutuhkan lahan yang luas, energi besar dan biaya perawatan yang mahal. Jakarta yang merupakan kota besar dengan lahan yang terbatas, sudah tidak memungkinkan untuk menggunakan pengolahan limbah secara konvensional seperti lagoon dan trickling filter. Sehingga perlu digunakan teknologi pengolahan limbah yang dapat dioperasikan di lahan yang terbatas tetapi memiliki effisiensi yang baik dalam penurunan parameter pencemar pada air limbah.

Daerah komersial seperti perkantoran dan perdagangan di Jakarta sebenarnya sejak lama telah memilik IPAL dengan sistem pengolahan lumpur aktif. Tetapi dengan meningkatnya jumlah penduduk yang berdampak terhadap meningkatnya jumlah limbah yang dihasilkan mengakibatkan lumpur aktif yang digunakan menjadi kurang efektif untuk mengolah air limbah. Di samping itu, peraturan yang ketat dalam pengolahan air limbah mengakibatkan IPAL-IPAL tersebut tidak dapat digunakan kembali dikarenakan air hasil olahannya berada di atas baku mutu. Tindakan dengan mengganti sistem pengolahan air limbah menjadi cukup sulit di Jakarta, karena lahan yang tersedia sangat terbatas. Jadi, salah satu cara yang dapat digunakan adalah dengan memodifikasi lumpur aktif yang telah ada.

Salah satu teknologi pengolahan limbah yang dapat digunakan adalah dengan menggunakan proses Moving Bed Biofilm Reactor (MBBR). Pada prinsipnya, MBBR merupakan proses lumpur aktif yang ditingkatkan dengan menambahkan media (carrier) ke dalam reaktor aerasi. Media-media tersebut memiliki luas permukaan yang besar untuk mengoptimalkan kontak antara air limbah, udara dan mikroorganisme.

Pada proses MBBR memungkinkan terjadinya dua proses pengolahan limbah yakni, proses biakan tersuspensi (suspended growth) dan proses biakan merekat (attached growth) secara bersama-sama. Dengan demikian, diharapkan akan meningkatkan jumlah mikroorganisme di dalam reaktor dan meningkatkan effisiensi penurunan zat pencemar.

Penelitian ini dilakukan untuk mengetahui penurunan zat organik (BOD dan COD) dan suspended solids dengan menggunakan proses moving bed biofilm reactor pada limbah domestik.

\subsection{Tujuan Penelitian}

Tujuan dari penelitian adalah untuk mengetahui pengaruh waktu tinggal hidrolik terhadap efisiensi peghilangan zat organik dan padatan tersuspensi di dalam air limbah doemstik dengan menggunakan proses moving bed biofilm reactor (MBBR).

\subsection{Lokasi Penelitian}

Penelitian variasi waktu tinggal hidrolik dalam menurunkan zat organik (BOD,COD) dan suspended solids pada air limbah domestik menggunakan moving bed biofilm reactor berlokasi di gedung Badan Pengkajian dan Penerapan Teknologi (BPPT), jalan $\mathrm{MH}$ Thamrin no 8, Jakarta. 


\section{TINJAUAN PUSTAKA}

\subsection{Pengoalahan Air Limbah dengan Proses Moving Bed Biofilm Reactor (MBBR)}

Sistem moving bed biofilm reactor adalah sebuah konsep yang sangat efektif dalam pengolaha limbah cair secara biologis, konsep ini pertama kali ditawarkan oleh pemerintah Norwegia pada tahun 1980 yang bertujuan untuk mengurangi beban nitrogen dalam air laut. Sistem ini dikembangkan berdasarkan konsep biofilm treatment yang diintegrasikan di dalam sistem lur

konvensional. (Odegaard et al., 1999)

Ide dasar dari sistem ini adalah untuk mendapatkan sistem pengolahan air limbah dengan operasi yang berjalan terus menerus (continut, reaktor yang non clogging (tidak dapat buntu) yaı tidak membutuhka backwash, sedikit menurunkan kehilangan tekanan (headloss), dan luas permukaan biofilm yang besar. Hal ini didapatkan dengan pertumbuhan biofilm/biomass di dalam media (biocarrier) kecil yang bergerak di dalam reaktor. (Ravichandran \& Joshua, 2012).

Dalam sistem ini, bahan pencemar (substrat) yang terkandung dalam air limbah akan tercampur sempurna di dalam sebuah reaktor, dimana mikroorganisme yang hidup di dalam limbah akan tumbuh melekat di media plast biocarrier) dan terakumulasi membentuk lapisan biomassa (biofilm) pada permukaan media tersebut. Media-media tersebut memungkinkan konsentrasi biomassa yang tinggi terjadi di dalam reaktor jika dibanc proses biakan tersuspensi, seperti proses lum konvensional $\mathrm{Hal}$ ini dapat meningkatkan kapasitas pengolahan biologis pada volume reaktor yang sama, sehinggamenghasilkan effisiensi yang lebih baik.

Media plastik biocarrier) didesain sedemikian rupa sehingga memiliki kepadatan unsur yang lebih rendah dibandingkan dengan air, serta menyediakan luas permukaan yang besar sebagai tempat tumbuh dan berkembangnya mikroorganisme.

Salah satu biocarrier yang seringkali digunakan dalam sistem ini adalah Media Biofilm Kaldnes 1 (K1), media ini dibuat dari bahan High Density polyethylene (HDPE) dengan berat jenis $\pm 0,95 \mathrm{~g} / \mathrm{cm}^{3}$ dan berbentuk silinder kecil, menyilang di dalamnya dan menyerupai sirip di luarnya . Silindernya memiliki panjang $7 \mathrm{~mm}$ dan diamter $10 \mathrm{~mm}$ (tidak terma siripnya). Media ini dapat menyediakan luas permukaan yang cukup besar untuk melekatnya bakteri ( $\pm 500 \mathrm{~m}^{2} / \mathrm{m}^{3}$ ). Belakangan ini, telah dilakukan beberapa percobaan terkait bentuk dan luas permukaan media dalam kemampuannya melekatkan bakteri pendegradasi. Di Norwegia, telah dibuat media yang lebih besar (K2) dengan bentuk yang mirip dengan panjang dan diameter $\pm 15 \mathrm{~mm}$.
Salah satu contoh bentuk media biocarrier yang digunakan dalam moving bed biofilm reactor dapat dilihat seperti p da Gambar 1.

Jumlah biocarrier yang dimasukkan ke dalam reaktor tergantung dari kualitas dan inffluent yang akan diolah, maximum filling sebesar \pm $70 \%$.
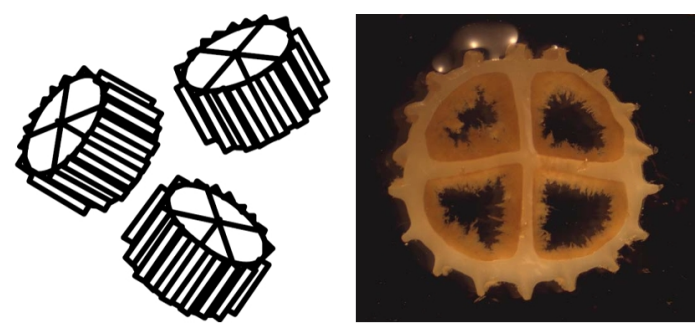

Gambar 1: Salah Satu Bentuk Media Biocarrier Yang Digunakan Dalam Moving Bed Biofilm Reactor.

Spesific surface area (SSA) atau luas permukaan spesifik media didefinisikan sebagai total luas permukaan media yang tersedia untuk biofilm per satuan volume reaktor. Jenis media biocarrier yang berbeda-beda memiliki karakteristiknya masir masing. Tabel 1 menggambarkan karakteristik $\mathrm{S}$ media dalam masing-masing sistem pengolahan.

Tabel 1 : Specific Surface Area Untuk Masing-Masing Sistem Pengolahan Dengan Pertumbuhan Mikroorganisme Melekat (Metcalf \& Eddy, 2003).

\begin{tabular}{|c|c|}
\hline Jenis Media & $\begin{array}{c}\text { Specific Surface Area } \\
\left(\mathrm{m}^{2} / \mathrm{m}^{3}\right)\end{array}$ \\
\hline Trickling Filter Media & $45-60^{*}$ \\
Rock & $90-150^{*}$ \\
Plast & $100-150^{*}$ \\
Rotating Biological Contractc & \\
MBBR Media : & 500 \\
Kaldnes K1 Media & 400 \\
Hydroxyl Media & 1200 \\
Kaldnes Flat Chip & \\
\hline
\end{tabular}

Di dalam reaktor, media plast Biocarrier akan berada dalam posisi bergerak, pergerakan ini disebabkan oleh energi sistem aerasi buatan yang berasal dari mesin blower/aerator ataupun dengan pengadukan mekanik secara konvensional (Henriksson, 2011). Mekanisme pergerakan media di dalam reaktor dapat dilihat pada Gambar 2.

Kemampuan sistem ini sangat baik pada kondisi pengadukan secara turbulensi, sehingga proses penyerapan oksigen pada substrat akan lebih optimal. Pengadukan yang lebih merat meningkatkan performa dari sistem pengolahan air limbah yang telah ada menjadi semakin Seperti pada proses biakan melekat lainnya, c dari senyawa yang masuk dan keluar pada biofilm 
memainkan peran penting. Karena pentingnya difı ketebalan dari biofilm menjadi sangat pent Biofilm yang ideal pada MBBR adalah tipis ( $\mu \mathrm{m})$ dan terdistribusi secara merata pada permukaan media (carrier). Agar bisa memperoleh hal itu, turbulensi pada reaktor sangatlah penting, baik untu menyalurkan substrat ke biofilm dan mempertahankan ketebalan yang rendah pada biofilm (Ødegaard, 1999).

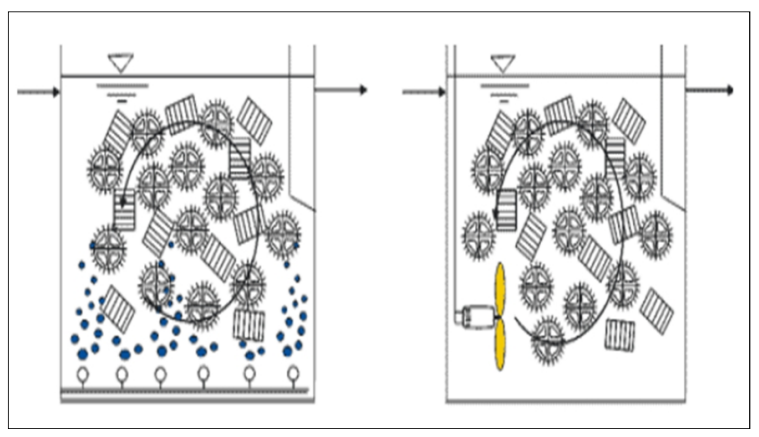

Gambar 2 : Mekanisme Pergerakan Biocarrier Oleh Aerasi Dan Pengadukan Dalam Sistem Moving Bed Biofilm Reactor.

Dalam beberapa kasus, dimana turbulensi terlalu rendah, biofilm yang dihasilkan sangat banyak hingga biofilm juga terbentuk di dalam rongga media, sehingga mempersempit lintasan air dan substrat untuk biofilm. Saat turbulensi cukup (baik disebabkan dari aerasi atau pengadukan), biofilm yang terbentuk cukup tipis dan men i secara merata semua permukaan media.

Reaktor Moving Bed Biofilm Reactor menggunakan saringan untuk memisahkan media biocarrier bergerak dalam reaktor dengan air olahan yang keluar sebagai overflow dari reaktor. Waktu tinggal media di dalam reaktor yan cukup, ditambah lagi dengan pengadukan substrat yang merata dalam air limbah mendorong seleksi dan pengayaan mikroba untuk tumbuh sesuai dengan konsentrasi substrat yang diterima oleh mikroba di dalam kondisi reaktor yang stabil.

Proses Moving Bed Biofilm dapat digunakan untuk berbagai aplikasi yang berbeda. Seperti pros penghilangan zat organik, proses penghilangan amoniak, proses nitrifikasi dan proses penghilangan nitrogen. Proses ini baik digunakan untuk pengolahan air limbah pada daerah perkotaan dan pengolahan air limbah industri.

Reaktor moving bed biofilm dapat dioperasikan dalam kondisi aerobik untuk penghilanganzat organik dan nitrifikasi atau dalam kondisi anoxic untuk denitrifikasi. Di dalam perancangan $M B B R$, terdapat beberapa parameter yang dianggap penting dan sangat mempenga efisiensi pengolahan, parameter tersebut ialah :
- Organicloading rate, yaitu kadar organik polutan yang dapat diukur dengan jumlah $\mathrm{kg} \mathrm{BOD}_{5}$, dihitung per satuan volume dalam sehari. ( $\mathrm{Kg}$ $\mathrm{BOD} / \mathrm{m}^{3}$.hari)

- Fill medium loading rate, ini adalah jumlah mikroorganisme yang menempel di media biocarrier per satuan luas dalam satuan waktu. $\left(\mathrm{Kg} / \mathrm{m}^{2}\right.$.hari)

- Dissolved Oxygen, yaitu kadar kandungan oksigen terlarut di dalam air di hitung berdasarkan satuan $\mathrm{gr} / \mathrm{m}^{3}$.

- Hydraulic Loading Rate, adalah waktu ting yang dibutuhkan air limbah di dalam reaktor yang dipenuhi media biocarrier.

- Spesific surface area, adalah jumlah luas permukaan media biocarrier yang tersedia untuk biofilm per volume unit media. $\left(\mathrm{m}^{2}\right.$ media/ $/ \mathrm{m}^{3}$ ).

Kriteria desain lengkap untuk MBBR yang dapat digunakan dapat dilihat pada Tabel 2 berikut :

Tabel 2 : Kriteria Desain Pengolahan dengan Sistem Moving Bed Biofilm Reactor (John Brinkley dkk ).

\begin{tabular}{|l|c|c|}
\hline \multicolumn{1}{|c|}{ Parameter } & Value & Units \\
\hline Anoxic HRT & $0,5-2,0$ & Hours \\
\hline Aerobic HRT & $1-4$ & Hours \\
\hline $\begin{array}{l}\text { Biofilm Surface Area of } \\
\text { Carrier }\end{array}$ & $500-1200$ & $\mathrm{~m}^{2} / \mathrm{m}^{3}$ \\
\hline $\begin{array}{l}\text { Biomass per Units } \\
\text { Surface Area }\end{array}$ & $5-25$ & $\mathrm{~g} \mathrm{TS} / \mathrm{m}^{2}$ \\
\hline BOD SALR & $7,5-25$ & $\mathrm{~g} / \mathrm{m}^{2} . \mathrm{d}$ \\
\hline COD SALR Clarifier & $15-50$ & $\mathrm{~g} / \mathrm{m}^{2} . \mathrm{d}$ \\
\hline $\mathrm{NH}_{4}-\mathrm{N} \mathrm{SALR}$ & $0,45-1,00$ & $\mathrm{~g} / \mathrm{m}^{2} \cdot \mathrm{d}$ \\
\hline $\begin{array}{l}\text { Secondary } \\
\text { Overflow Rate }\end{array}$ & $\mathrm{gpd} /{ }^{2}$ \\
\hline
\end{tabular}

Proses Moving Bed Biofilm telah dapat digunakan untuk berbagai aplikasi yang berbeda. Seperti proses penghilangan zat organik, proses penghilangan amoniak, proses nitrifikasi dan proses penghilangan senyawa. Proses ini baik digunakan untuk pengolahan air limbah pada daerah perkotaan dan pengolahan air limbah industri.

Pre-settling biasanya dipakai sebagai pengolahan awal terutama untuk menghindari penyumbatan pada bioreaktor. Pengendap awal bukanlah suatu prasyaratan, namun sangat sering digunakan untuk menambah fleksibilitas, misalnya dengan melakukan proses koagulasi.

Dalam penyisihan zat organik, proses Moving Bed Biofilm biasa didesain dengan volumetric loading 4-5 $\mathrm{kg} \mathrm{BOD} / \mathrm{m}^{3}$.hari, dengan pengisian media sebanyak $67 \%\left(335 \mathrm{~m}^{2} / \mathrm{m}^{3}\right)$ dan temperatur $150^{\circ} \mathrm{C}$. Ini disesuaikan dengan beban BOD berdasarkan luas permukaan media yakni $15 \mathrm{~g} \mathrm{BOD} / \mathrm{m}^{2}$.hari, hal ini 
lebih besar dari pada proses RBC yang telah di desain dengan tujuan yang sama.

MBBR dapat digunakan bersamaan dengan proses lumpur aktif untuk meningkatkan proses pengolahan limbah. Tingkat penyisihan organik yang sangat tinggi bisa diperoleh saat jumlah bebannya tinggi. Hal ini mengindikasikan bahwa proses ini mungkin dikhususkan untuk perencanaan pengolahan high rate. Misalnya, dapat digunakan sebagai tahap pertama penyisihan karbon dalam proses dua langkah dengan lumpur aktif sebagai tahap kedua.

Dalam beberapa kasus, MBBR dapat diletakkan secara langsung di depan instalasi pengolahan Lumpur aktif tanpa tahap lanjutan apapun, atau dapat diberi bak pengendap atau pemisahan lanjutan setelah melalui MBBR. Keuntungan memiliki pemisahan lanjutan adalah produksi lumpur pada MBBR tidak akan mempengaruhi umur lumpur pada proses lumpur aktif. Sedangkan kekurangan dengan tidak adanya pemisahan lanjutan, selain menghindari biaya investasi yang besar, juga karena sifat pemisahan pada lumpur aktif dapat ditingkatkan.

\subsection{Perencanaan Proses MBBR}

MBBR dirancang berdasarkan pada surface area loading rate (SALR) atau beban luas permukaan media/reaktor untuk jenis polutan tertentu (BOD, COD, $\mathrm{NH}_{4}-\mathrm{N}$ dan lain-lain). Desain MBBR biasanya ditentukan secara spesifik dengan uji coba guna mengembangkan grafik penyisihan polutan berdasarkan luas permukaan. Namun data-data ekstensif mengenai hal ini telah dihasilkan 15 tahun terakhir untuk berbagai jenis komposisi air limbah, kecuali untuk air limbah industri tertentu (John Brinkley et al, n.d).

SLAR untuk tingkat penyisihan polutan ditentukan berdasarkan luas permukaan biofilm yang diperlukan. Luas permukaan efektif media biofilm dapat ditentukan berdasarkan volume media. Volume media yang biasa digunakan adalah maksimalnya $67 \%$ dari volume reaktor. Jika lebih dari $67 \%$ maka akan menghambat pola aliran limbah di dalam reaktor sehingga biofilm tidak terbentuk secara merata di permukaan media.

\section{MATERIAL DAN METODA PERCOBAAN}

\subsection{Material}

\subsubsection{Air Limbah}

Air limbah yang diolah dalam penelitia bersumber dari salah satu bak pengumpul limbah domestik kantor BPP Jakarta Pusat.

\subsubsection{Media Biofilm}

Media biofilm yang digunakan adalah media dari bahan thermoplast tip bioball golf dengan spesifikasi seperti yang terlihat pada Tabel :

Tabel 3 : Spesifikasi Media Penyangga.

\begin{tabular}{|lll|}
\hline Tipe & $:$ & Bioball Golf \\
\hline Material & $:$ & Thermoplast \\
\hline Diameter & $:$ & $3 \mathrm{~cm}$ \\
\hline $\begin{array}{l}\text { Luas } \\
\text { Spesifik }\end{array}$ & $: \pm 210 \mathrm{~m}^{2} / \mathrm{m}^{3}$ \\
\hline $\begin{array}{l}\text { Berat } \\
\text { Spesifik } \\
\text { Media }\end{array}$ & $:$ & $164,34 \mathrm{~kg} / \mathrm{m}^{3}$ \\
\hline Berat Jenis & $:$ & $0,970 \mathrm{~kg} / \mathrm{m}^{3}$ \\
\hline Porositas & $:$ & 0,75 \\
\hline Warna & $:$ & Hitam \\
\hline
\end{tabular}

\subsubsection{Bahan Analisa Parameter (Reagen)}

Bahan yang digunakan untuk analisis dalam penelitian ini dapat dilihat pada Tabel ،

\subsubsection{Reaktor Percobaan}

Bahan yang digunakan sebagai reaktor adalah 2 unit tangki plastik kapasitas 120 liter dan 1 unit rofil tangki kapasitas 250 liter. Sedangkan untuk bahan distribusi air perpipaan digunakan pipa AW PVC $\varnothing 1 / 2$ inci, 1 inci, 2 inci, selang $\varnothing 1$ inci, selang $\varnothing 10 \mathrm{~mm}$, elbow, tee, valve, klep, dan penutup pipa. Skema alat penelitian diawali dengan bak penampung, tangki reaktor $M B B R$, dan diakhiri dengan bak pengendap akhir.

\subsubsection{Alat}

Alat yang digunakan dalam penelitian ini adalah sebagai berikut :

- $\quad$ Pompa celup merk ATMAN, spesifikasi Qmax 5400 L/jam ; Head 5 m

- Pompa aquarium merk AQUARIA, spesifikasi Qmax 2000 L/jam ; Head 1,8 m

- Pompa merk AQURA, spesifikasi Qmax 2400 L/jam; Head $2 \mathrm{~m}$

- Blower Aerasi merk ATMAN tipe GF-150 dan JEBO P-70

- Difuser gelembung halus (fine bubble)

- $\quad$ Spectofotometer DR 2800

- Gelas ukur kimia100 ml

- $\quad$ Hmeter Hydrotester

- Mikro Pipet $10 \mathrm{ml}$ 


\subsection{Metoda Penelitian}

\subsubsection{Penentuan Lokasi Instalasi Alat Penelitian}

Lokasi pengambilan air limbah yang akan diolah adalah pada salah satu bak penampung air limbah domestik gedung perkantoran BPPT Jakarta Pusat. Skema proses pengolahan dapat dilihat pada Gambar 6.

\subsubsection{Perancangan Alat Penelitian}

Penelitian ini dilakukan dalam skala kecil (Pilot Plan) dengan kapasitas pengolahan sebesar 217 Liter. Rancangan alat pengolahan terdiri atas 1 buah bak penampung yang terbuat dari tangki plastik kapasitas maksimum 120 liter, 1 buah tangki untuk reaktor MBBR berkapasitas maksimum 250 liter yang diisi dengan media penyangga sebanyak $20 \%$, dan 1 buah reaktor pengendap akhir yang terbuat dari tangki plastik berkapasitas 120 liter. Skema rancangan alat penelitian seperti yang dapat dilihat pada Gambar 3.

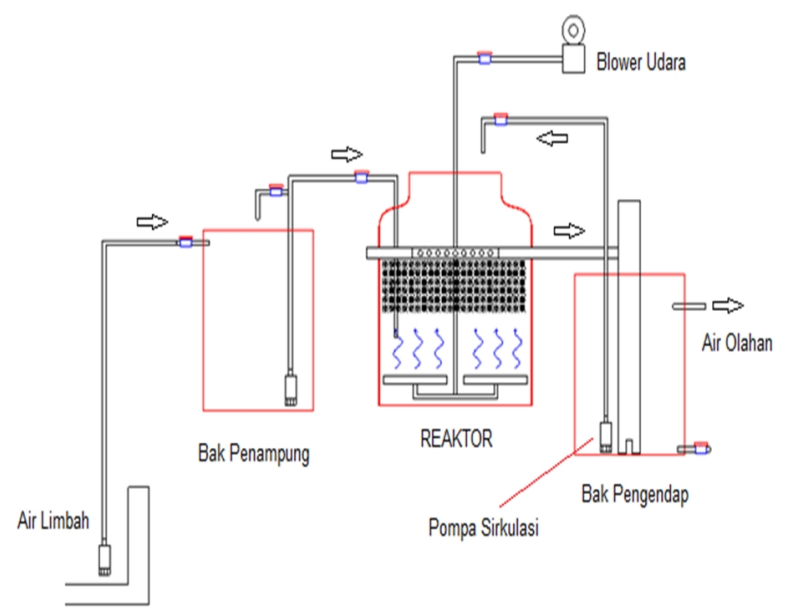

Gambar 3 : Skema Rancangan Alat Penelitian.

\subsubsection{Tahapan Pelaksanaan Penelitian}

\subsubsection{Tahap Pembuatan Alat}

Untuk reaktor aerob dibuat dengan profil tank dengan kapasitas 250 liter. Volume efektif yang digunakan adalah 218 liter. Di dalam reaktor aerob dibuat weir dari pipa 1,5 inci yang telah diberi lubang dengan diameter $25 \mathrm{~mm}$ dengan menggunakan bor. Untuk difuser, digunakan jenis fine bubble berbentuk disc dengan diameter $30 \mathrm{~cm}$ sebanyak dua buah. Untuk blower digunakan merk Jebo kapasitas 70 liter/menit. Untuk mengatur debit udara dari blower digunakan valve.
Bak pengumpul dibuat dengan mengunakan gentong air dengan ukuran 120 liter. Fungsi dari bak pengumpul adalah untuk menstabilkan debit yang akan masuk ke dalam reaktor aerob. Di dalam bak pengumpul diberi pompa celup yang digunakan untuk memompa air limbah ke reaktor aerob.

Bak pengendap akhir yang akan digunakan dalam penelitian adalah gentong air dengan kapasitas 120 liter. Pada dasar bak pengendap dilakukan penyemenan untuk membuat slope sebagai ruang lumpur. Pada bak pengendap akhir akan dibuat weir dengan menggunakan pipa 4 inci. Waktu tinggal pada bak pengendap akhir sama dengan debit limbah masuk dan tidak diperhitungkan secara lebih detail. Untuk proses resirkulasi, dilakukan dengan mengunakan pompa akuarium dengan rasio resirkulasi adalah $100 \%$.

\subsubsection{Tahap Pengoperasian Alat}

Pada tahap ini, air limbah domestik dari sum pit dipompakan menuju bak pengumpul, selanjutnya, air limbah kembali dipompakan menuju reaktor MBBR. Didalam reaktor MBBR yang telah diisi dengan media bioball, air limbah akan mengalami pengadukan yang disebabkan oleh adanya proses aerasi yang merata dengan menggunakan blower. Selanjutnya limpasan (over flow) dari reaktor MBBR dialirkan ke bak pengendap akhir.

Di dalam reaktor MBBR, mikroorganisme pendegradasi zat polutan air limbah akan terdapat pada dua tempat, yakni mikroorganisme akan tersuspensi di dalam air limbah dan sebagian lagi akan melekat dan membentuk biofilm di media bioball. Sehingga pada reaktor MBBR tersebut akan terjadi dua proses pengolahan biologis, yakni proses pengolahan biologi secara tersuspensi dan proses pengolahan biologi secara melekat.

Pada penelitian kali ini, akan terdiri dari beberapa proses, yakni :

a. Proses Pengembang-biakan mikroorganisme dan Aklimatisasi.

Proses ini dilakukan untuk mengembang biakan mikroorganisme, dilakukan secara alami dengan cara mengalirkan air limbah domestik seca kontinyu ke dalam reaktor biofilter. Dalam proses telah terbentuk lapisan biofilm yang menye media bioball. Sedangkan aklimatisasi merupak pengadaptasian mikroorganisme terhadap air buangan yang akan diolah. Proses aklimatisc berjalan selama 2 minggu dengan waktu tingga jam dengan debit 18 liter/jam. Akhir dari aklimatisa adalah ketika effisiensi $p \epsilon$ runan konsentrasi COD dan Amoniak relatif stabi 
b. Proses Penentuan Waktu Optimal

Setelah proses seeding dan aklimatisć selanjutnya masuk ke proses penentuan waktu optimal. Pada proses ini, waktu tinggal menjadi 8 jam, 6 jam dan 4 jam.

\subsubsection{Tahap Pengujian Sampel}

Pengujian sampel dilakukan secara periodik. Sampling Point ditetapkan diambil pada bak penampung dan outlet bak pengendap akhir. Dalam penelitian ini dilakukan analisis terhadap karakteris air limbah domestik yang diol yakni saat sebelum (influen) dan sesudah (efluen) memasuki pengolahan. Parameter yang diuji adalah COD, TSS dan $\mathrm{pH}$. Metode analisis untuk berbagai parameter yang diteliti dapat dilihat pada - 4. Hasil analisis mengacu pada baku mutu air limbah , berdasarkan PerGub DKI Jakarta No.122 Tahun 2005.

Tabel 4 : Metode Analisis Parameter Metode Analisa Parameter.

\begin{tabular}{|c|c|c|c|}
\hline $\begin{array}{l}\mathbf{N} \\
\mathbf{0}\end{array}$ & $\begin{array}{c}\text { Paramete } \\
r\end{array}$ & MetodeAnalisa & Keterangan \\
\hline 1 & COD & $\begin{array}{l}\text { USEPA Reactor } \\
\text { Digestiol } \\
\text { Method } \\
\text { (Method 8000) }\end{array}$ & $\begin{array}{l}\text { Spektrofotometer } \\
\text { DR } 2800 \text { COD Low } \\
\text { Range } \lambda 430 \mathrm{~nm}\end{array}$ \\
\hline 2 & BOD & $\begin{array}{l}\text { Respirometric, } \\
2005\end{array}$ & - \\
\hline 3 & TSS & $\begin{array}{c}\text { Photometric } \\
\text { Method } \\
\text { (Method 8006) }\end{array}$ & $\begin{array}{c}\text { Spektrofotometer } \\
D R 2800 \\
\lambda 630 \mathrm{~nm} \\
\end{array}$ \\
\hline 4 & $\mathrm{pH}$ & $\begin{array}{c}\text { pHmetri } \\
\text { instrument }\end{array}$ & $\begin{array}{c}\text { pHmeterHydrotes } \\
\text { ter } \mathrm{PH}-80\end{array}$ \\
\hline 5 & Suhu & Thermometer & $\begin{array}{c}\text { pHmeterHydrotes } \\
\text { ter } \mathrm{PH}-80\end{array}$ \\
\hline
\end{tabular}

\section{HASIL PENELITIAN DAN PEMBAHASAN}

\subsection{Air Limbah}

Air limbah yang digunakan sebagai penelitian adalah air limbah domestik, baik grey water maupun black water yang berasal dari gedung Badan Pengkajian dan Penerapan Teknologi (BPPT) di Jakarta. Grey water merupakan limbah yang bersumber dari kegiatan non-toilet seperti limbah buangan dapur, kantin, kamar mandi dan kegiatan pencucian di lingkup kantor BPPT. Sedangkan black water merupakan limbah yang berasal dari kegiatan toilet di gedung BPPT.

\subsection{Karakteristik Air Limbah}

Air limbah domestik yang berasal dari gedung BPPT memiliki kualitas yang kurang baik bila dibandingkan dengan peraturan yang terkait dengan standar kualitas air limbah domestik. Peraturan yang digunakan sebagai standar untuk air limbah domestik adalah KEPMEN LH no. 112 tahun 2003 tentang Baku Mutu Air Limbah Domestik dan PERGUB DKI Jakarta no. 122 tahun 2005 tentang Pengelolaan Air Limbah Domestik Di Provinsi Daerah Khusus Ibukota Jakarta.

Berdasarkan hasil uji kualitas air limbah sebelum dilakukan pengolahan dapat dilihat pada Tabel 5. Berdasarkan Tabel 5 dapat dilihat bahwa BOD, COD, TSS dan amoniak berada diatas baku mutu. Bila kandungan BOD dan COD dalam air limbah tinggi, berati zat organik dalam air limbah juga tinggi. Kadar oksigen dalam dalam air limbah akan menurun karena dipakai untuk menguarai zat organik Rendahnya kandungan oksigen di suatu perairan akan mengakibatkan rusaknya lingkungan perairan yaitu adanya kematian berbagai organisme sehingga menurunkan kualitas perairan tersebut (Utomo, 2002).

Tabel 5 : Kualitas Air Limbah Domestik Gedung BPPT (Hasil Penelitian, 2013).

\begin{tabular}{|l|c|c|c|c|c|}
\hline \multirow{2}{*}{ Parameter } & \multirow{2}{*}{ Unit } & \multirow{2}{*}{ Kadar } & $\begin{array}{c}\text { Kadar } \\
\text { Maksimum }\end{array}$ & \multicolumn{2}{|c|}{ Kadar Maksimum** } \\
\cline { 5 - 7 } & & & Individual & Komunal \\
\hline BOD & $\mathrm{mg} / \mathrm{l}$ & 195 & 100 & 75 & 50 \\
\hline $\mathrm{COD}$ & $\mathrm{mg} / \mathrm{l}$ & 264 & - & 100 & 80 \\
\hline TSS & $\mathrm{mg} / \mathrm{l}$ & 246 & 100 & 50 & 50 \\
\hline $\mathrm{pH}$ & - & 9 & $6-9$ & $6 \mathrm{~s} / \mathrm{d} 9$ & $6 \mathrm{~s} / \mathrm{d} 9$ \\
\hline Amoniak & $\mathrm{mg} / \mathrm{l}$ & 92,2 & - & 10 & 10 \\
\hline
\end{tabular}

* Standar Baku Mutu KEPMEN LH No. 112 tahun 2003

**Standar Baku Mutu PERGUB DKI Jakarta No. 122 tahun 2005

Kandungan padatan tersuspensi yang tinggi akan menyebabkan terjadinya kekeruhan dan warna pada air limbah, hal ini dapat merusak pemandangan. Padatan tersuspensi juga dapat menyebabkan pendangkalan di perairan, ini dikarenakan padatan yang tersuspensi dapat berupa tanah erosi, lumpur dan liat. Selain itu, penetrasi cahaya matahari ke permukaan dan bagian yang lebih dalam di perairan tidak berlangsung efektif karena terhalang padatan tersuspensi sehingga fotosintesis berlangsung tidak sempurna dan juga menyebabkan oksigen di perairan berkurang. Air limbah dapat mempengaruhi kualitas badan air penerima jika dibuang secara terus menerus. Oleh karena itu, perlu dilakukan pengolahan air limbah. 


\subsection{Tingkat Biodegradabilitas Air Limbah}

Air limbah dapat dikelompokan berdasarkan tingkat biodegradabilitas, tingkat biodegradabilitas pada suatu limbah dinyatakan dengan perbandingan antara nilai BOD dengan nilai COD. Air limbah yang tergolong biodegradabilitas tinggi memiliki rasio BOD/COD sekitar 0,65 , sedangkan yang tergolong biodegradabilitas sedang memiliki rasio $\mathrm{BOD} / \mathrm{COD}$ sekitar 0,32 dan yang tergolong biodgradable rendah memiliki rasio BOD/COD sekitar 0,16 (Mulyani, 2012). Berdasarkan hasil penelitian yang dilakukan, rasio rata-rata BOD terhadap COD influen adalah 0,588. Tingkat biodegradabilitas yang tinggi ini mengindikasikan bahwa zat organik yang terkandungan pada limbah tersebut mampu diuraikan dengan baik oleh mikroorganisme, sehingga pengolahan dengan mengunakan MBBR yang merupakan pengolahan air limbah secara biologis memberikan keuntungan lebih dibandingkan pengolahan secara kimia maupun fisika. Keuntungankeuntungan tersebut antara lain polutan pencemar di air limbah dapat diurai oleh mikroorganisme. Selain itu, efisiensi penyisihan yang terjadi tinggi karena mikroorganisme yang hidup di dalam reaktor tersuspensi pada air limbah dan juga melekat pada media, serta tidak ada penambahan zat kimia dalam proses pengolahannya.

\subsection{Proses Seeding dan Aklimatisasi}

Sebelum MBBR digunakan untuk penelitian, terlebih dahulu dilakukan proses seeding dan aklimatisasi. Seeding adalah proses pembenihan mikrooganisme di dalam reaktor hingga terbentuk lapisan biofilm di media. Setelah lapisan biofilm pada media terbentuk selanjutnya dilakukan proses aklimatisasi. Aklimatisasi adalah proses pengadaptasian mikroorganisme yang ada di dalam reaktor agar mikroorganisme dapat tumbuh di permukaan media dan di dalam limbah (tersuspensi). Pada penelitian ini, aklimatisasi dilakukan dengan waktu tinggal hidrolik (WTH) 12 jam selama 18 hari dan ditandai dengan efisiensi penurunan COD yang sudah stabil. Hasil pengukuran konsentrasi COD influen dan efluen selama proses seeding dapat dilihat pada Gambar 4.

Berdasarkan hasil pengamatan setelah 7 hari, proses pengolahan di dalam reaktor masih kurang baik. Ini terlihat dari efisiensi penurunan COD yang masih sekitar 70\%. Hal ini disebabkan karena mikroorganisme di dalam reaktor belum tumbuh secara optimal. selain itu, kebutuhan oksigen di dalam reaktor kurang karena kinerja blower mengalami penurunan sehingga kondisi di dalam reaktor berubah menjadi anoksik. Anoksik adalah keadaan air limbah di dalam reaktor dengan sedikit oksigen. Pada saat kinerja blower dalam keadaan baik, kondisi di dalam reaktor menjadi cukup oksigen dan bakteri aerob tumbuh dangan baik untuk mengurai zat organik. Tetapi ketika kinerja blower mengalami penurunan, oksigen di dalam reaktor berkurang menyebabkan bakteri aerob yang tumbuh di dalam reaktor mati sehingga efisiensi penyisihannya menurun.

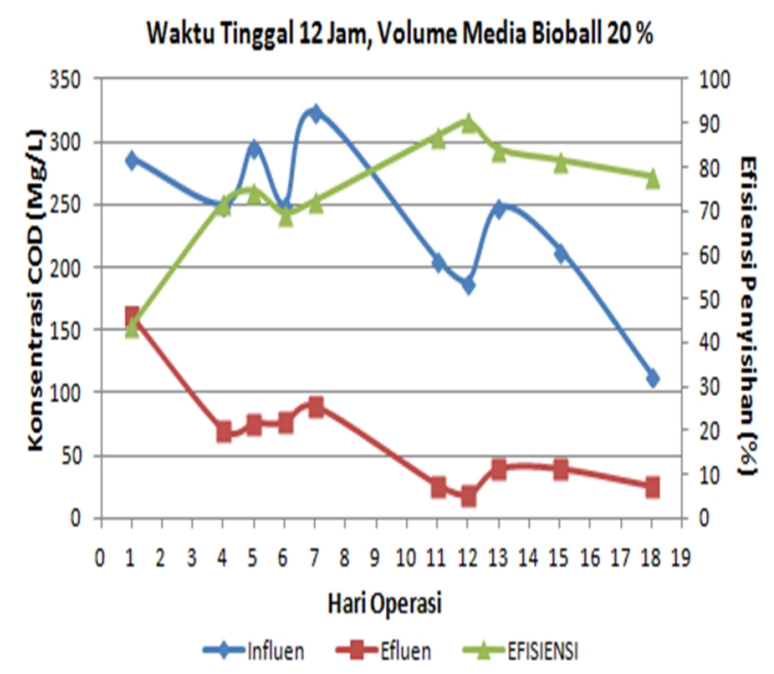

Gambar 4 : Konesentrasi COD Infulen Dan Efluen Selama Proses Seeding Dan Aklimatisasi (Hasil Penelitian, 2013).

Pada pengamatan hari ke-11, efisiensi penurunan COD mulai meningkat hingga mencapai $87 \%$ dengan konsentrasi COD efluen adalah $26 \mathrm{mg} / \mathrm{I}$ jauh dibawah baku mutu. Ini menandakan bahwa mikrooganisme di dalam reaktor sudah tumbuh dan berkembang biak dengan baik. Di dalam reaktor sudah terlihat lapisan mikroorganisme yang melekat pada permukaan media bioball. Dengan adanya lapisan mikroorganisme yang berada di permukaan media, penguraian senyawa polutan pencemar pada air limbah semakin efektif.

Berdasarkan Gambar 4 tersebut dapat dilihat bahwa pada hari ke-11 hingga hari ke-15 efisiensi penurunan COD berada pada kisaran antara $81,77 \%$ $92,17 \%$. Tetapi pada hari ke-18 (aklimatisasi terakhir), efisiensi penyisihan mengalami penurunan hingga $78 \%$ dengan konsentarsi COD influen adalah $114 \mathrm{mg} / \mathrm{l}$ sedangkan konsentrasi COD efluen sebesar $25 \mathrm{mg} / \mathrm{l}$.

Konsentrasi rata-rata COD influen pada WTH 12 jam adalah $192 \mathrm{mg} / \mathrm{l}$, sedangkan konsentrasi ratarata COD efluen adalah $34,3 \mathrm{mg} / \mathrm{I}$ dengan efisiensi penyisihan mencapai $81,37 \%$. Konsentrasi rata-rata COD influen dan efluen serta efisiensi penyisihan dihitung berdasarkan data pada hari ke-13 hingga ke18. Ini dikarenakan pada hari ke-13 hingga ke-18 efisiensi penyisihan COD relatif lebih stabil. 
Hasil pengukuran konsentrasi TSS selama proses seeding dapat dilihat pada Gambar 5 . Penurunan TSS terjadi dengan sangat baik, ini dapat dilihat pada Gambar 5 dimana efisiensi penurunannya cukup stabil pada kisaran antara 80,19\% - 93\% dengan efisiensi penurunan tertinggi adalah $93 \%$ pada hari ke-13 dan efisiensi penurunan terendah adalah $80,19 \%$ pada hari ke-18. Konsentrasi rata-rata TSS influen pada WTH 12 jam adalah 207,3 $\mathrm{mg} / \mathrm{l}$, sedangkan konsentrasi rata-rata TSS efluen adalah $21 \mathrm{mg} / \mathrm{l}$ dengan efisiensi penyisihan mencapai $90 \%$.

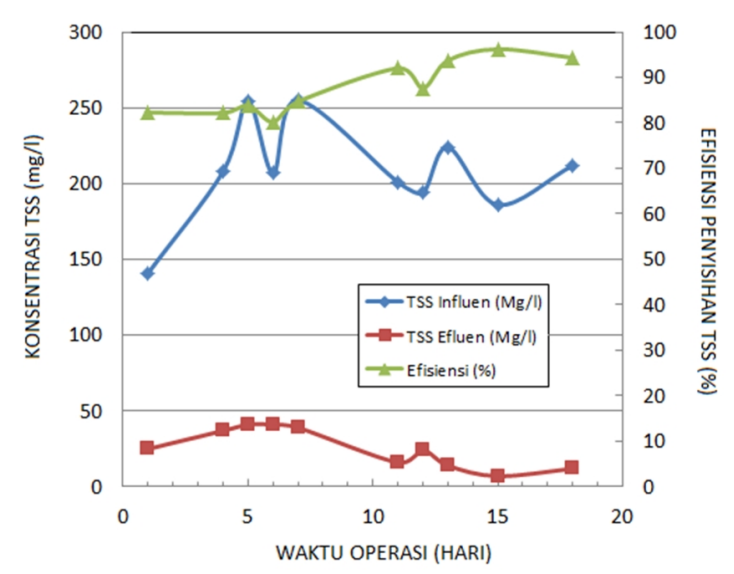

Gambar 5: Grafik Penghilangan TSS pada seeding dan aklimatisasi (Hasil Penelitian, 2013).

\subsection{Pengaruh Waktu Tinggal Terhadap Efisiensi Pengolahan}

\subsubsection{Pengaruh Waktu Tinggal Terhadap Penyisihan COD}

Setelah proses aklimatisasi berjalan dengan baik yang ditunjukan dengan efisiensi penurunan COD meningkat dan stabil, maka pengoperasian dilanjutkan dengan mengubah waktu tinggal hidrolik (WTH) di dalam reaktor menjadi 8 jam, 6 jam dan 4 jam, untuk mengetahui pengaruhnya terhadap penyisihan COD. Pengaturan WTH dilakukan dengan mengatur debit air yang masuk ke dalam reaktor menggunakan valve dan mengukur laju alirnya. Rasio resirkulasi yang digunakan adalah $100 \%$ dan volume media adalah $20 \%$ dari volume reaktor. Konsentrasi COD influen dan efluen serta efisiensi penyisihan COD di dalam reaktor MBBR dengan beberapa variasi waktu tinggal setelah proses seeding selengkapnya dapat dilihat pada Gambar 6.

Pada pengoperasian dengan waktu tinggal 8 jam, konsentrasi rata-rata COD influen adalah 246,3 $\mathrm{mg} / \mathrm{l}$ sedangkan konsentrasi rata-rata COD efluen adalah $27,7 \mathrm{mg} / \mathrm{l}$ dengan efisiensi penyisihan ratarata mencapai $88,72 \%$. Berdasarkan data hasil penelitian (Gambar 6) konsentrasi COD yang masuk ke dalam reaktor sangat bervariasi yakni berkisar antara 140 - 269 mg/l. Efisiensi penyisihan COD yang terjadi berkisar antara 72,86 - 90,53\% dengan penyisihan tertinggi terjadi pada hari ke-10 dan penyisihan terendah terjadi pada hari ke-2. Air limbah domestik yang diolah dengan MBBR pada waktu tinggal 8 jam mampu menurunkan konsentrasi COD hingga di bawah baku mutu yang telah ditetapkan oleh Kementrian LH dan PerGub DKI Jakarta. Seperti yang tertera pada Gambar 6, dimana konsentrasi COD efluen terendah adalah $25 \mathrm{mg} / \mathrm{l}$ dan konsentrasi COD efluen tertinggi adalah $66 \mathrm{mg} / \mathrm{l}$.

Pada pengoperasian dengan waktu tinggal 6 jam, konsentrasi rata-rata COD influen adalah 327,67 $\mathrm{mg} / \mathrm{l}$ sedangkan konsentrasi rata-rata COD efluen adalah $48 \mathrm{mg} / \mathrm{l}$ dengan efisiensi penyisihan rata-rata mencapai $85,48 \%$. Berdasarkan data hasil penelitian (Gambar 6) terdapat perbedaan konsentrasi COD yang masuk ke dalam reaktor. Konsentrasi COD tertinggi yang masuk ke reaktor terjadi pada hari ke16 yakni sebesar $423 \mathrm{mg} / \mathrm{l}$ sedangkan konsentrasi COD terkecil terjadi pada hari ke-17 yakni sebesar 226 mg/l. Efisiensi penyisihan COD cukup bervariasi dimana efisiensi penyisihan tertinggi terjadi pada hari ke-18 sebesar $86,45 \%$ dan efisiensi terendah terjadi pada hari ke-11 sebesar $82,04 \%$. Air limbah domestik yang diolah dengan MBBR pada waktu tinggal 6 jam mampu menurunkan konsentrasi COD hingga di bawah baku mutu yang telah ditetapkan oleh Kementrian LH dan PerGub DKI Jakarta. Seperti yang tertera pada Gambar 6, dimana konsentrasi COD efluen terendah adalah $32 \mathrm{mg} / \mathrm{l}$ dan konsentrasi COD efluen tertinggi adalah $66 \mathrm{mg} / \mathrm{l}$.

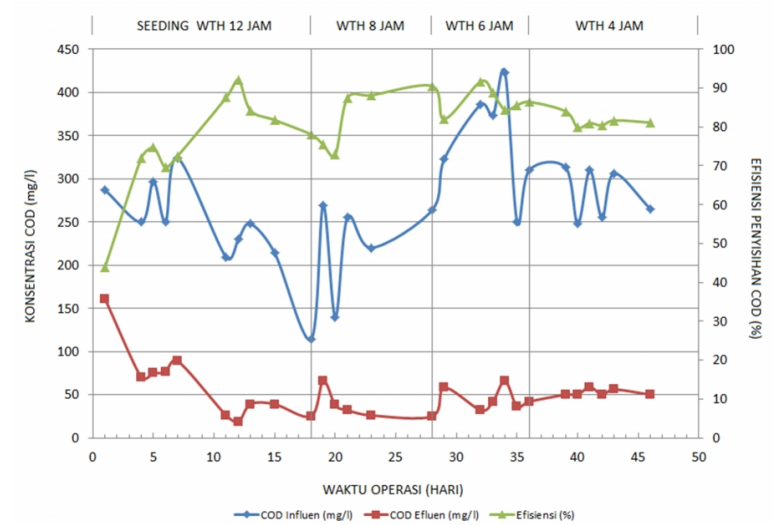

Gambar 6 : Grafik Konsentrasi COD Sebelum Dan Sesudah Pengolahan Serta Efisiensi Penyisihan COD Dengan Kondisi Berbagai Variasi Waktu Tinggal Hidrolik (WTH) (Hasil Penelitian, 2013).

Pada pengoperasian dengan waktu tinggal 4 jam, konsentrasi rata-rata COD influen adalah 275,33 $\mathrm{mg} / \mathrm{l}$ sedangkan konsentrasi rata-rata COD efluen adalah $52 \mathrm{mg} / \mathrm{l}$ dengan efisiensi penyisihan rata-rata mencapai $81,07 \%$. Berdasarkan data hasil penelitian 
(Gambar 6) terdapat perbedaan konsentrasi COD yang masuk ke dalam reaktor. Konsentrasi COD tertinggi yang masuk terjadi pada hari ke-21 yakni sebesar $313 \mathrm{mg} / \mathrm{l}$ sedangkan konsentrasi COD terkecil terjadi pada hari ke-22 yakni sebesar $248 \mathrm{mg} / \mathrm{l}$. Efisiensi penyisihan COD cukup bervariasi dimana efisiensi penyisihan tertinggi terjadi pada hari ke-25 sebesar $81,70 \%$ dan efisiensi terendah terjadi pada hari ke-22 sebesar 79,8\%. Air limbah domestik yang diolah dengan MBBR pada waktu tinggal 4 jam mampu menurunkan konsentrasi COD hingga di bawah baku mutu yang telah ditetapkan oleh Kementrian LH dan PerGub DKI Jakarta.Seperti yang tertera pada Gambar 6, dimana konsentrasi COD efluen terendah adalah $50 \mathrm{mg} / \mathrm{l}$ dan konsentrasi COD efluen tertinggi adalah $59 \mathrm{mg} / \mathrm{l}$.

Dari hasil penelitian yang telah dilakukan. Efisiensi penyisihan COD mengalami penurunan seiring dengan penurunan waktu tinggal (WTH), ini didasarkan pada efisiensi penyisihan COD rata-rata pada masing-masing waktu tinggal (WTH). Penurunan ini terjadi karena kontak air limbah dengan mikroorganisme yang terjadi di dalam reaktor menjadi lebih singkat, sehingga proses degradasi COD dan polutan pencemar lainnya menjadi lebih kecil.

Pada grafik diatas, dapat dilihat pada hari ke-1 dan ke-2, efisiensi penyisihan COD mengalami penurunan, ini disebabkan karena terjadinya perubahan WTH dari 12 jam menjadi 8 jam. Begitu pula yang terjadi pada hari ke-11 karena terjadinya perubahan WTH 8 jam menjadi 6 jam, serta pada hari ke-21 dan ke-22 yang terjadi karena perubahan WTH 6 jam menjadi 4 jam. Penurunan efisiensi pada saat pergantian WTH terjadi karena adanya perubahan debit aliran dari pengoperasian sebelumnya sehingga beban hidroliknya menjadi lebih besar. Beban hidrolik yang lebih besar dari pengoperasian sebelumnya menyebabkan mikroorganisme yang berada di dalam reaktor akan mengalami proses pengadaptasian kembali dalam mengurai zat organik pada air limbah, sehingga pada hari pertama dan kedua setelah pergantian waktu tinggal efisiensi penyisihannya akan mengalami penurunan. Efisiensi penyisihan akan kembali menjadi stabil antara 2 - 3 hari setelah pergantian WTH.

Penyisihan COD terjadi karena mikroorganisme yang hidup di dalam reaktor mengurai zat organik pada air limbah domestik. Udara yang diinjeksikan melalui blower menciptakan suasana aerobik di dalam reaktor sehingga yang bertugas mereduksi zat organik adalah mikroorganisme aerob. Secara umum penyisihan COD dapat dilihat pada reaksi berikut :

$$
\begin{aligned}
\text { mikroba } & \text { Senyawa Organik }+\mathrm{O}_{2} \rightarrow \\
\mathrm{CO}_{2} & +\mathrm{H}_{2} \mathrm{O}+\text { Sel Baru } \\
& + \text { Energi }
\end{aligned}
$$

Hasil dari reduksi zat organik tersebut menghasilkan zat-zat yang relatif lebih stabil seperi $\mathrm{CO}_{2}$ dan $\mathrm{H}_{2} \mathrm{O}$, selain itu terbentuk pula biomasa dan energi yang dimanfaatkan untuk proses metabolisme mikroorganisme. Metabolisme yang terjadi oleh mikroorganisme terdiri dari proses katabolisme dan anabolisme. Proses katabolisme yang terjadi adalah proses oksidasi dan respirasi, dimana pada proses ini zat organik yang di urai oleh mikroorganisme menghasilkan energi untuk pertumbuhan bakteri. Sedangkan proses anabolisme terjadi untuk berkembang biak bakteri dengan menfaatkan energi yang diperoleh dari proses oksidasi dan respirasi.

Injeksi udara yang dilakukan tidak hanya digunakan untuk menambahkan oksigen ke dalam reaktor, tetapi juga digunakan untuk proses pengadukan dengan memanfaatkan turbulensi dari udara. Pengadukan ini berfungsi untuk meratakan zat organik di seluruh volume reaktor sehingga dapat diurai oleh mikroorganisme. Selain itu untuk menjaga agar media tetap bergerak sehingga kontak antara mikroorganisme yang melekat di media dengan zat organik dalam air limbah semakin sempurna.

\subsubsection{Pengaruh Waktu Tinggal Terhadap Penyisihan BOD}

Selain COD, salah satu parameter air limbah lainnya adalah BOD. Fungsi BOD sangat mirip dengan COD yaitu mengukur jumlah materi-materi organik di dalam air. Meskipun demikian, COD tidak spesifik karena mengukur apa pun yang dapat dioksidasi secara kimiawi sedangkan BOD hanya memperhitungkan aktivitas biologis organik seperti bakteri, alga dan sebagainya. Penyisihan BOD pada pada penelitian ini dapat dilihat pada Gambar 7.

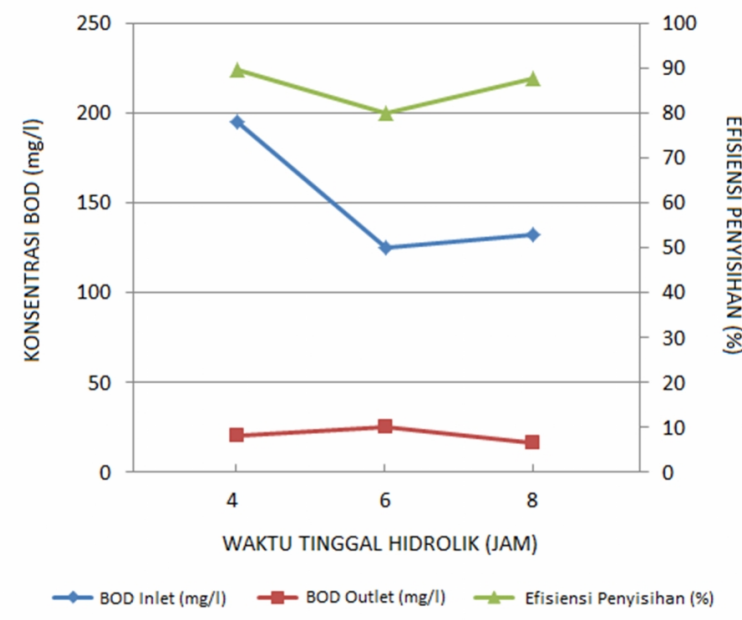

Gambar 7 : Grafik penyisihan BOD Terhadap variasi Waktu tinggal hidrolik (WTH) (Hasil Penelitian, 2013). 
Pengukuran nilai BOD dilakukan pada hari terakhir pengoperasian pada masing-masing WTH, yakni hari ke-18 pada proses aklimatisasi (WTH 12 Jam), hari ke-10 pada WTH 8 jam, hari ke-18 pada WTH 6 jam dan hari ke-28 pada WTH 4 jam. pengukuran nilai BOD yang dilakukan hanya sekali pada masing-masing waktu tinggal (WTH), ini dikarenakan pengujian sampel untuk parameter BOD membutuhkan waktu yang cukup lama. Selain itu, nilai BOD juga dapat diwakili oleh nilai COD

Pada pengoperasian dengan waktu tinggal hidrolik (WTH) 12 jam, konsentrasi BOD influen adalah $108 \mathrm{mg} / \mathrm{l}$ sedangkan konsentrasi BOD efluen adalah $19 \mathrm{mg} / \mathrm{l}$ dengan efisiensi penyisihan mencapai 82,4\%. Pada pengoperasian dengan WTH 8 jam, konsentrasi BOD influen adalah $195 \mathrm{mg} / \mathrm{l}$ sedangkan BOD efluen adalah $20 \mathrm{mg} / \mathrm{l}$ dengan efisiensi penyisihan mencapai $89,7 \%$. Pada pengoperasian dengan WTH 6 jam, konsentrasi BOD influen adalah $126 \mathrm{mg} / \mathrm{l}$ sedangkan BOD efluen adalah $25 \mathrm{mg} / \mathrm{l}$ dengan efisiensi penyisihan mencapai $80,15 \%$. Pada pengoperasian dengan WTH 4 jam, konsentrasi BOD influen adalah $132 \mathrm{mg} / \mathrm{l}$ sedangkan BOD efluen adalah $16 \mathrm{mg} / \mathrm{l}$ dengan efisiensi penyisihan mencapai $87,88 \%$.

Tingginya nilai BOD di dalam air limbah mengindikasikan bahwa air limbah tersebut memiliki kandungan zat organik yang tinggi. Zat organik yang dapat disisihkan secara biologis tergantung dari jumlah oksigen terlarut, jenis mikroorganisme dan jumlah zat pengurai. Adanya oksigen menyebabkan proses oksidasi aerob dapat berlangsung, bahanbahan organik akan berubah menjadi produk-produk yang lebih stabil dan sisanya akan disintesis menjadi mikroba baru.

Berdasarkan penelitian yang dilakukan, Air limbah domestik yang diolah dengan menggunakan MBBR pada WTH 12 jam, 8 jam, 6 jam dan 4 jam dapat menurunkan konsetrasi BOD hingga dibawah baku mutu yang telah ditetapkan oleh Kementrian LH dan PerGub DKI Jakarta.

Ada beberapa kendala yang dihadapi dalam pengoperasian alat pada saat penelitian. Kendala tersebut berupa debit air limbah yang masuk ke dalam reaktor mengalami penurunan dan bahkan tidak mengalir karena terjadinya penyumbatan di dalam pipa. Hal ini menyebabkan beban hidrolik di dalam reaktor berubah dan efisiensi penyisihan BOD mengalami penurunan

\subsubsection{Pengaruh Waktu Tinggal Terhadap Penyisihan TSS}

Konsentrasi TSS influen dan efluen serta efisiensi penyisihan TSS di dalam reaktor MBBR dengan beberapa variasi waktu tinggal setelah proses seeding selengkapnya dapat dilihat pada Gambar 8.
Pada pengoperasian dengan waktu tinggal 8 jam, konsentrasi rata-rata TSS influen adalah 199 $\mathrm{mg} / \mathrm{l}$ sedangkan konsentrasi rata-rata TSS efluen adalah $16 \mathrm{mg} / \mathrm{l}$ dengan efisiensi penyisihan rata-rata mencapai 92\%. Berdasarkan data hasil penelitian (Tabel 11) konsentrasi TSS yang masuk ke dalam reaktor sangat bervariasi yakni berkisar antara 133 $308 \mathrm{mg} / \mathrm{l}$. Efisiensi penyisihan TSS yang terjadi berkisar antara 87 - 95\% dengan penyisihan tertinggi terjadi pada hari ke-2 dan penyisihan terendah terjadi pada hari ke-3. Air limbah domestik yang diolah dengan MBBR pada waktu tinggal 8 jam mampu menurunkan konsentrasi TSS hingga di bawah baku mutu yang telah ditetapkan oleh Kementrian LH dan PerGub DKI Jakarta. Seperti yang tertera pada tabel 4.8 , dimana konsentrasi TSS efluen terendah adalah $12 \mathrm{mg} / \mathrm{l}$ dan konsentrasi TSS efluen tertinggi adalah $22 \mathrm{mg} / \mathrm{l}$.

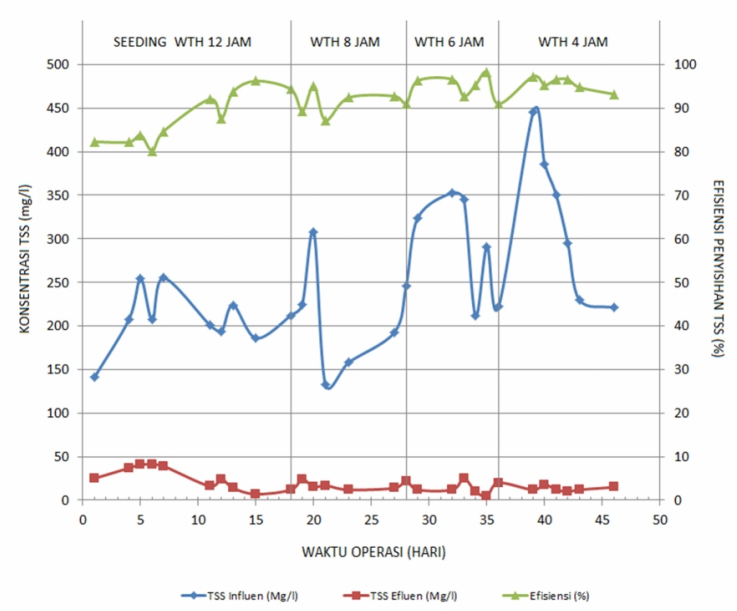

Gambar 8 : Penyisihan TSS Di Dalam Reaktor MBBR Pada Kondisi berbagai Waktu Tinggal (Hasil Penelitian, 2013).

Pada pengoperasian dengan waktu tinggal 6 jam, konsentrasi rata-rata TSS influen adalah 241,7 $\mathrm{mg} / \mathrm{l}$ sedangkan konsentrasi rata-rata TSS efluen adalah $11,7 \mathrm{mg} / \mathrm{l}$ dengan efisiensi penyisihan ratarata mencapai 94,85\%. Berdasarkan data hasil penelitian (Gambar 8) terdapat perbedaan konsentrasi TSS yang masuk ke dalam reaktor. Konsentrasi TSS tertinggi yang masuk terjadi pada hari ke-15 yakni sebesar $353 \mathrm{mg} / \mathrm{l}$ sedangkan konsentrasi TSS terkecil terjadi pada hari ke-16 yakni sebesar $212 \mathrm{mg} / \mathrm{l}$. Efisiensi penyisihan TSS cukup bervariasi dimana efisiensi penyisihan tertinggi terjadi pada hari ke-17 sebesar 98\% dan efisiensi terendah terjadi pada hari ke-18 sebesar 90\%. Air limbah domestik yang diolah dengan MBBR pada waktu tinggal 6 jam mampu menurunkan konsentrasi TSS hingga di bawah baku mutu yang telah ditetapkan oleh Kementrian LH dan PerGub DKI Jakarta. Seperti yang tertera pada Gambar 8, dimana 
konsentrasi TSS efluen terendah adalah $5 \mathrm{mg} / \mathrm{l}$ dan konsentrasi TSS efluen tertinggi adalah $25 \mathrm{mg} / \mathrm{l}$.

Pada pengoperasian dengan waktu tinggal 4 jam, konsentrasi rata-rata TSS influen adalah 248,7 $\mathrm{mg} / \mathrm{l}$ sedangkan konsentrasi rata-rata TSS efluen adalah $12,3 \mathrm{mg} / \mathrm{l}$ dengan efisiensi penyisihan ratarata mencapai $94,86 \%$. Berdasarkan data hasil penelitian (Gambar 8) terdapat perbedaan konsentrasi TSS yang masuk ke dalam reaktor. Konsentrasi TSS tertinggi yang masuk terjadi pada hari ke-21 yakni sebesar $445 \mathrm{mg} / \mathrm{l}$ sedangkan konsentrasi TSS terkecil terjadi pada hari ke-28 yakni sebesar $221 \mathrm{mg} / \mathrm{l}$. Efisiensi penyisihan TSS cukup bervariasi dimana efisiensi penyisihan tertinggi terjadi pada hari ke-21 sebesar 97\% dan efisiensi terendah terjadi pada hari ke-28 sebesar 93\%. Air limbah domestik yang diolah dengan MBBR pada waktu tinggal 4 jam mampu menurunkan konsentrasi TSS hingga di bawah baku mutu yang telah ditetapkan oleh Kementrian LH, PerGub DKI Jakarta. Seperti yang tertera pada Gambar 8, dimana konsentrasi TSS efluen terendah adalah $10 \mathrm{mg} / \mathrm{l}$ dan konsentrasi TSS efluen tertinggi adalah $18 \mathrm{mg} / \mathrm{l}$.

Komposisi TSS terdiri dari zat organik dan anorganik seperti lumpur. Tingginya efisiensi penyisihan yang terjadi pada TSS disebabkan penyisihan TSS terjadi di dua tempat, yakni di reaktor dan bak pengendap. Di reaktor TSS yang berupa zat organik di reduksi oleh mikroorganisme, sedangkan TSS berupa flok lumpur diendapkan di bak pengendap. Pada Gambar 8 dapat dilihat trend penyisihan TSS yang terjadi selama penelitian. Rising sludge pada bak pengendap akhir sering terjadi pada penelitian. Rising sludge adalah proses naiknya lumpur yang berada di dasar bak pengendap ke permukaan. Ini disebabkan proses resirkulasi lumpur atau pengembalian lumpur yang terjadi tidak berjalan dengan baik. Pengendapan yang terlalu cepat terjadi di bak pengendap, selanjutnya dalam suasana lumpur yang anaerobik terjadi reaksi denitrifikasi dan menyebabkan flok lumpur ikut naik bersamaan dengan naiknya gas Nitrogen $\left(\mathrm{N}_{2}\right)$. Selain itu, pompa yang digunakan untuk proses resirkulasi tidak mampu menyedot lumpur dengan baik. Kendala lainnya adalah debit resirkulasi yang sering mengalami penurunan bahkan tidak mengalir karena terjadinya penyumbatan di dalam pipa.

Padatan tersuspensi yang ada di dalam air terdiri dari berbagai macam zat, misalnya pasir halus, liat dan lumpur yang merupakan bahan-bahan anorganik atau dapat pula berupa bahan-bahan organik yang melayang-layang dalam air. Bahanbahan organik yang merupakan zat tersuspensi terdiri dari berbagai jenis senyawa seperti selulosa, lemak, protein yang melayang-layang dalam air atau dapat juga berupa mikroorganisme bakteri, algae dan sebagainya. Bahan-bahan organik ini selain berasal dari sumber alamiah juga berasal dari buangan kegiatan manusia seperti kegiatan industri, pertanian, pertambangan atau kegiatan rumah tangga.

\subsection{Efisiensi Alat Terhadap Waktu Tinggal Hidrolik}

Efisiensi penyisihan rata-rata COD, BOD dan TSS berdasarkan waktu tinggal hidrolik (WTH) 8, 6 dan 4 jam dapat dilihat pada Tabel 6 .

Tabel 6 : Efisiensi Penyisihan Rata-Rata BOD, COD dan TSS.

\begin{tabular}{|c|c|c|c|}
\hline Parameter & $\begin{array}{c}\text { WTH } \\
\text { 8 Jam }\end{array}$ & $\begin{array}{c}\text { WTH } \\
\text { 6 Jam }\end{array}$ & $\begin{array}{c}\text { WTH } \\
\text { 4 Jam }\end{array}$ \\
\hline BOD & $89,7 \%$ & $80,15 \%$ & $87,88 \%$ \\
\hline COD & $88,72 \%$ & $85,48 \%$ & $81,07 \%$ \\
\hline TSS & $92,06 \%$ & $94,85 \%$ & $94,86 \%$ \\
\hline
\end{tabular}

Berdasarkan Tabel 6 tersebut di atas, hingga pengoperasian dengan WTH 4 jam, reaktor masih mampu menghilangkan polutan organik dengan baik, dengan efisiensi penyisihan BOD, COD dan TSS berada di atas $80 \%$. Sehingga pengoperasian MBBR dengan WTH yang lebih kecil masih mungkin untuk dilakukan. Pengoperasian MBBR dengan WTH yang lebih kecil memiliki keuntungan yakni selain karena waktu tinggal yang singkat, air limbah yang akan diolah akan lebih banyak dan biaya yang dibutuhkan akan lebih kecil karena reaktor yang digunakan juga kecil.

MBBR merupakan pengolahan air limbah secara biologis, sehingga semakin lama WTH-nya maka efisiensi penyisihan COD akan semakin besar. Berdasarkan hasil penelitian, MBBR sangat efisien dioperasikan pada WTH 4 jam, ini dikarenakan efisiensi penyisihanya masih sangat tinggi yakni $81 \%$. Selain itu, jika dioperasikan dalam kapasitas yang lebih besar, jumlah limbah yang diolah akan lebih banyak tetapi reaktor yang digunakan akan lebih kecil dan lahan yang dibutuhkan juga tidak terlalu luas. Hal ini tentu akan mempermudah baik dari segi operasional maupun biaya yang dikeluarkan.

\subsection{Hubungan Antara Beban Organik (COD Loading) Dengan Efisiensi Penyisihan}

Dari hasil penelitian dapat dibuat hubungan antara besarnya beban organik (COD Loading) terhadap efisiensi penyisihan beban COD. Beban organik adalah jumlah senyawa organik (COD atau BOD) yang masuk ke dalam bioreaktor per satuan volume reaktor per satuan waktu, yang dinyatakan sebagai berat organik per satuan volume reaktor per 
hari. Hubungan antara beban COD yang masuk ke dalam reaktor dengan efisiensi penyisihan COD dapat dilihat pada Gambar 9.

Pada Gambar 9, beban COD yang digunakan berdasarkan pada data COD influen pada 3 pengukuran terakhir pada pengoperasian masingmasing WTH. Ini dikarenakan pada 3 pengukuran terakhir efisiensi penurunan COD relatif lebih stabil dibandingkan pada pengukuran diawal WTH.

Dari hasil perhitungan pada Gambar 9 dapat diplot dalam bentuk grafik hubungan antara beban COD dengan efisiensi penurunan seperti terlihat pada Gambar 9. Berdasarkan Gambar 9 tersebut, dapat ditarik kesimpulan bahwa semakin besar beban COD yang masuk ke reaktor, maka efisiensi penyisihan COD akan semakin kecil. Pola penurunan efisiensi penyisihan COD mengikuti persamaan linear $y=-6,6552 x+93,305$ dengan 6,6552 adalah konstanta penyisihan COD, $x=$ beban $\operatorname{COD}(\mathrm{Kg}$ $\mathrm{COD} / \mathrm{m}^{3}$.hari) dan $\mathrm{y}=$ efisiensi $\operatorname{COD}(\%)$. Tanda negatif pada persamaan tersebut berarti semakin besar beban organik maka efisiensi penyisihannya semakin menurun. Sedangkan faktor determinasinya $\left(R^{2}\right)$ adalah $72,76 \%$. Dari hasil tersebut dapat diketahui bahwa dengan beban COD 0,5 - 1,5 Kg $\mathrm{COD} / \mathrm{m}^{3}$.hari, efisiensi penyisihan COD berkisar antara 83,32 - 89,98\%.

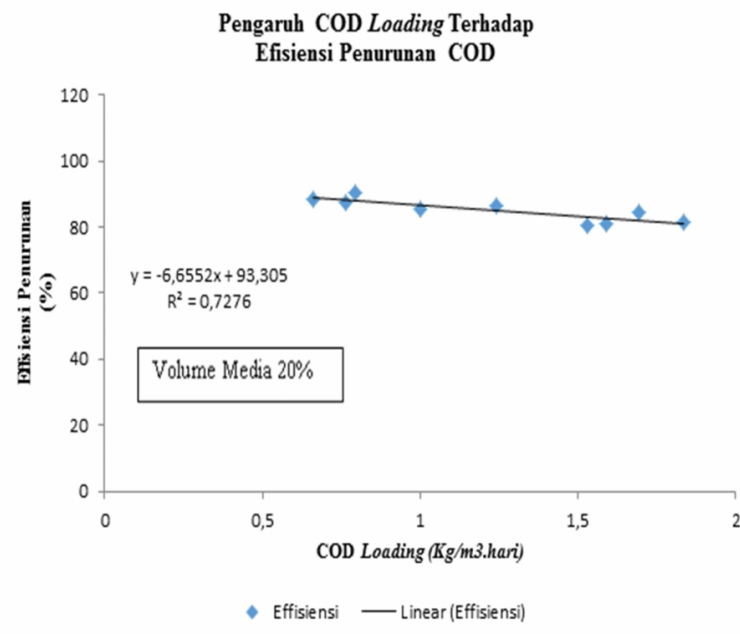

Gambar 9 : Grafik Hubungan Antara Beban COD Dengan Efisiensi Penyisihan Dalam Reaktor MBBR (Hasil Perhitungan).

\subsection{Pengukuran pH Selama Penelitian}

Selama penelitian dilakukan pengamatan terhadap $\mathrm{pH}$ influen dan $\mathrm{pH}$ efluen. Berdasarkan hasil pengukuran $\mathrm{pH}$ yang dilakukan, $\mathrm{pH}$ air limbah yang masuk ke reaktor memiliki kondisi basa (>7). Hasil pengukuran $\mathrm{pH}$ air limbah sebelum dan sesudah pengolahan di dalam reaktor MBBR dapat dilihat pada Gambar 10.

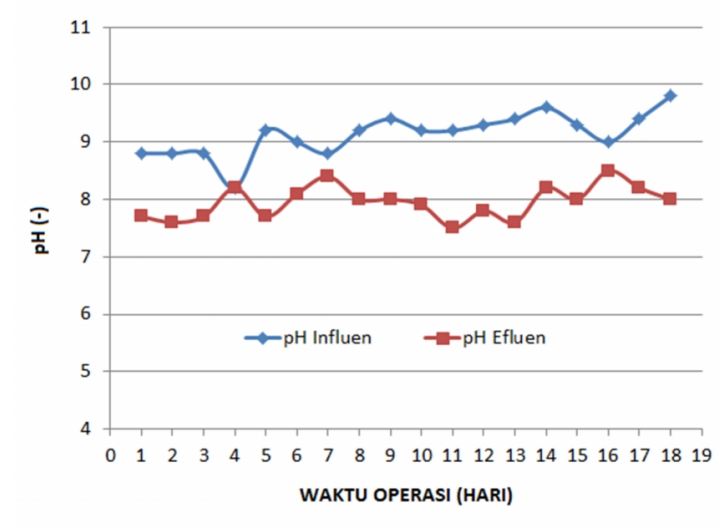

Gambar 10 : pH Influen Dan Efluen Selama Penelitian.

Nilai pH influen akan mempengaruhi jenis mikroorganisme yang hidup di dalam reaktor. Mikroorganisme-mikroorganisme tersebut akan melekat pada permukaan media dan juga tersuspensi di air limbah dan selanjutnya akan mengurai polutan pencemar. Berdasarkan pH-nya, mikroorganisme dapat dikelompokan menjadi 3 yaitu mikroorganisme asidofil yakni kelompok mikroorganisme yang dapat hidup $\mathrm{pH} 6-8$ dan $\mathrm{pH} 2-5$, mikroorganisme mesofil yakni kelompok mikroorganisme yang dapat hidup pada $\mathrm{pH} \mathrm{5,5} \mathrm{-} 8$ dan mikroorganisme alkafil yakni kelompok mikroorganisme yang dapat hidup pada $\mathrm{pH}$ 8,4-9,5 (Brooks, 1994). Dari hasil pengukuran, nilai $\mathrm{pH}$ influen yang terjadi selama penelitian berkisar antara 8,2 - 9,8. Hal ini mengindikasikan mikroorganisme yang hidup di dalam reaktor adalah kelompok mikroorganisme alkafil. Dari Gambar 10 terlihat bahwa $\mathrm{pH}$ efluen turun sekitar satu poin yakni dari $\mathrm{pH}$ influen rata-rata 9 turun menjadi sekitar 8.

Penurunan $\mathrm{pH}$ kemungkinan disebabkan karena reaksi nitrifikasi yang terjadi didalam reaktor biofilter aerob. Reaksi nitrifikasi adalah reaksi konversi amoniak menjadi nitrat secara biologis oleh bakteria chemoautotrophic yang terjadi dalam dua tahap (Chen and Richard Liew, 2002).

Tahap 1 : Nitrosomonas, Nitrosospira, Nitrosococcus dan Nitrosolobus.

$\mathrm{NH}_{4}{ }^{+}+1,44 \mathrm{O}_{2}+0,0496 \mathrm{CO}_{2} \rightarrow 0,01 \mathrm{C}_{3} \mathrm{H}_{7} \mathrm{O}_{2} \mathrm{~N}+$

$0,990 \mathrm{NO}_{2}{ }^{-}+0,970 \mathrm{H}_{2} \mathrm{O}+1,99 \mathrm{H}^{+}$

Tahap 2 : Nitrobacter, Nitrospina dan Nitrococcus. $\mathrm{NO}_{2}{ }^{-}+0,00619 \mathrm{NH}_{4}{ }^{+}+0,50 \mathrm{O}_{2}+0,031 \mathrm{CO}_{2}+0,0124$ $\mathrm{H}_{2} \mathrm{O} \rightarrow 0,00619 \mathrm{C}_{3} \mathrm{H}_{7} \mathrm{O}_{2} \mathrm{~N}+0,984 \mathrm{NO}_{3}{ }^{-}+0,00619 \mathrm{H}^{+}$

Reaksi Overall :

$\mathrm{NH}_{4}{ }^{+}+1,89 \mathrm{O}_{2}+0,0805 \mathrm{CO}_{2} \rightarrow 0,0161 \mathrm{C}_{3} \mathrm{H}_{7} \mathrm{O}_{2} \mathrm{~N}+$ $0,984 \mathrm{NO}_{3}^{-}+0,952 \mathrm{H}_{2} \mathrm{O}+1,98 \mathrm{H}^{+}$ 
Proses nitrifikasi menghasilkan asam nitrat dan dalam keadaan kemampuan buffer larutan yang rendah akan dapat menyebabkan penurunan $\mathrm{pH}$ secara drastis (significant). $1 \mathrm{mg} \mathrm{NH}-\mathrm{N}$ dapat mereduksi alkalinitas sebesar 7,14 g (sebagai $\mathrm{CaCO}_{3}$ ).

Sama halnya dengan $\mathrm{pH}$, kondisi suhu berpengaruh terhadap jenis mikroorganisme yang hidup dalam reaktor. Suhu memegang peranan penting dalam bagi keberlangsungan proses pengolahan secara biologis di dalam reaktor. Berdasarkan hasil pengukuran, suhu influen berada pada kisaran antara $28,4-30,8{ }^{\circ} \mathrm{C}$, ini mengindikasikan bahwa jenis mikroorganisme yang hidup dalam reaktor dan berperan dalam penguraian polutan pencemar adalah kelompok mikroorganisme mesofil. Mikroorganisme mesofil adalah kelompok mikroorganisme yang dapat hidup pada suhu 20 $45^{\circ} \mathrm{C}$.

\section{KESIMPULAN}

Dari hasil penelitian tersebut dapat simpulkan:

1. Untuk penyisihan COD, pada pengoperasian dengan WTH 12 jam, 8 jam, 6 jam dan 4 jam efisiensi penyisihannya masing-masing mencapai $81,37 \%, 88,72 \%, 85,48 \%$ dan $81,07 \%$. Untuk penyisihan BOD, pada pengoperasian dengan WTH 12 jam, 8 jam, 6 jam dan 4 jam efisiensi penyisihannya masing-masing mencapai $82,4 \%$, $89,7 \%, 80,15 \%$ dan $87,88 \%$. Untuk penyisihan TSS, pada pengoperasian dengan WTH 12 jam, 8 jam, 6 jam dan 4 jam efisiensi penyisihannya masingmasing mencapai 90,5\%, 92,06\%, 94,85\% dan $94,86 \%$.

2. Waktu tinggal hidrolik terkecil yang dapat digunakan adalah 4 jam, dengan kualitas efluen telah memenuhi baku mutu sesuai dengan KEPMEN LH no. 112 tahun 2003 tentang Baku Mutu Air Limbah Domestik dan PERGUB DKI Jakarta no. 122 tahun 2005 tentang Pengelolaan Air Limbah Domestik Di Provinsi Daerah Khusus Ibukota Jakarta, yakni dengan nilai BOD, COD dan TSS masing-masing adalah $16 \mathrm{mg} / \mathrm{l}, 52 \mathrm{mg} / \mathrm{l}$ dan $12,3 \mathrm{mg} / \mathrm{l}$.

3. Berdasarkan hasil penelitian, semakin besar beban COD yang masuk ke dalam reaktor maka efisiensi penyisihannya akan menurun. Pola penurunan efisiensi penyisihan COD mengikuti persamaan $y=-6,6552 x+93,305$ dengan faktor deteminasi $\left(R^{2}\right) 72,74 \%$.

\section{DAFTAR PUSTAKA}

- Brooks et al., 1994, Mikrobiologi kedokteran edisi 2. Penerbit buku kedokteran EGC., Jakarta.
- Henriksson, Kristina., Tenfalt, Oscar., 2011, Measurements of Hydrolysis In Moving Bed Biofilm Reactor Carriers, Evaluation By Means of Oxygen Uptake Rate Measurements. Lund University : Lund.

- Keputusan Gubernur DKI Jakarta Nomor 122 Tahun 2005 Tentang Pengelolaan Air Limbah Domestik di Wilayah Prov. DKI Jakarta.

- Keputusan Menteri Lingkungan Hidup Nomor 112 tahun 2003. Tentang Baku Mutu Air Limbah Domestik.

- Metcalf \& Eddy., 2003, Wastewater Engineering : Treatment and Reuse, Fourth Edition, International Edition. McGraw-Hill., New York.

- Mulyani, Happy., 2012, Pengaruh Pre-Klorinasi Dan Pengaturan pH Terhadap Proses Aklimatisasi Dan Penurunan COD Pengolahan Limbah Cair Tapioka Sistem Anaerobic Baffled Reactor. Tesis . program pasca sarjana UNDIP., Semarang.

- Ødegaard, H., 1999, The Moving Bed Biofilm Reactor. Norwegian University of Science and Technology., Trondheim.

- P.E.B, Jhon., Johnson, C.H., Souza, Robert., n.d, Moving Bed Biofilm Reactor Technology - A FullScale Installation for Treatment of Pharmaceutical Wastewater., North Carolina.

- Pekerjaan Penentuan Standar Kualitas Air Limbah Yang Boleh Masuk Ke Dalam Sistem Sewerage PD PAL Jaya. Dwikarsa Envacotama. PD PAL Jaya Tahun 1995.

- Ravichandran.M and Joshua Amarnath.D. 2012. Performance Evaluation of Moving Bed Bio-Film Reactor Technology for Treatment of Domestic Waste Water in Industrial Are a at MEPZ (Madras Exports Processing Zone), Tambaram, Chennai, India. Elixir Pollution 53 (2012) 11741-11744

- Said, N.I., Utomo, Kristianti., 2007, Pengolahan Air Limbah Domestik Dengan Proses LumpurAktif Yang Diisi Dengan Media Bioball. BPPT., Jakarta.

- Said, Nusa Idaman., 2005, Aplikasi Bio-ball Untuk Media Biofilter Studi Kasus Pengolahan Air Limbah Pencucian Jean. BPPT., Jakarta.

- Said, Nusa Idaman., 2008, Pengolahan Air Limbah Domestik Di DKI Jakarta. " Tinjauan Permasalahan, Strategi dan Teknologi Pengolahan “. BPPT., Jakarta.

- Utomo, Kristrianti., 2002, Penyisihan COD, BOD, TSS, Ammonia Menggunakan Proses Biofilter Tercelup dengan Media Bioball secara Aerob (Studi Kasus Air Limbah Domestik Waduk Setiabudi Jakarta Selatan). Tugas Akhir. JurusanTeknik Lingkungan UNDIP., Semarang.

- W.F. Chen, J.Y. Richard Liew., 2002, The Civil Engineering Handbook, Second Edition. CSC Press. 